\title{
DISERTACIONES
}

\section{SONIC LOGOS: AN EXPERIMENTAL DESIGN ON SOUND FEATURES AND BRAND PERSONALITY}

\author{
Logos sonoros: un diseño experimental sobre los rasgos sonoros y la \\ personalidad de marca
}

\section{Logos sonoros: um desenho experimental sobre os rasgos sonoros e a personalidade de marca}

Lluís Mas, Universitat Pompeu Fabra, Barcelona (España)

lluis.mas@upf.edu

Received: January 03, 2018

Accepted: May 15, 2018

\section{ABSTRACT}

Sonic branding is the strategic use of sound to communicate the identity and values of a brand in the different touch points with its publics. The objective of this study is to determine which brand personality traits and self-reported emotions (calmness or excitement and pleasantness) are associated with different sonic logo features. The author conducted a $3 \times 3 \times 2$ within-subjects experiment -intensity (fade up, fade down, constant), pitch (ascending, descending, constant), and pace (fast, slow)-. These features are manipulated resulting in 18 versions of a 3-seconds sonic logo with 18 unknown brand names, embedded in a 9 seconds voice message. Results show that slow and fade up sonic logos are slightly more pleasant and simpler than fast and fade down sonic logos, and descending sonic logos are down-to-earth. Also, the combination of fade up and ascending pitch is less exciting and less aggressive than the 


\section{DISERTACIONES}

ESTUDIOS

El papel del sonido en la comunicación: contribución, funciones y efectos

ISSN: $1856-9536$

Doi: http://dx.doi.org/10.12804/revistas.urosario.edu.co/disertaciones/a.6373

Volumen 12, Número 2 / Julio-diciembre 2019

Versión PDF para imprimir desde

http://revistas.urosario.edu.co/index.php/disertaciones

combination of fade down and descending pitch. A deeper understanding of the processing of sound is required to further the theory on branding and have important practical implications for media production and advertising.

Keywords: Sound branding, sound features, brand personality, emotions, self-reported scales.

\section{RESUMEN}

La estrategia de marca sonora se refiere al uso estratégico del sonido para comunicar la identidad y valores de una marca en sus diferentes puntos de contacto con los públicos. El objetivo de este estudio es determinar qué rasgos de personalidad de marca y qué emociones autopercibidas (calma o excitación, y grado de agrado) son asociadas con los rasgos del logo sonoro. Se lleva a cabo un diseño experimental entre sujetos $3 \times 3 \times 2$-intensidad (en aumento, en disminución y constante), tono (ascendente, descendente y constante) y ritmo (rápido, lento)-. Las variaciones de estos rasgos dan como resultado 18 versiones del mismo logo sonoro. Este tiene una duración de 3 segundos y va acompañado de una marca desconocida y un mensaje de voz de 9 segundos. Los resultados indican que los logos sonoros más lentos y con una intensidad en aumento generan una sensación más agradable y de simplicidad que los logos rápidos y con intensidad en disminución. Por su parte, los logos sonoros con tono descendente son percibidos como más ordinarios. Así mismo, la combinación de intensidad en aumento y tono ascendente se percibe como menos emocionante y agresiva que la combinación de intensidad en disminución y tono descendente. El estudio de la percepción y procesamiento del sonido de marca puede contribuir a desarrollar las teorías sobre estrategias de marca y tener importantes aplicaciones en la producción de planes de comunicación estratégica.

Palabras clave: branding sonoro, rasgos sonoros, personalidad de marca, emociones, escalas autoperceptivas.

\section{RESUMO}

A estratégia de marca sonora refere-se ao uso estratégico do som para comunicar a identidade e valores de uma marca em seus diferentes pontos de contato com os públicos. 0 objetivo deste estudo é determinar que rasgos de personalidade de marca e que emoções auto percebidas (calma ou excitação, e grau de agrado) são associadas com os rasgos do logo sonoro. Leva-se a cabo um desenho experimental entre sujeito $3 \times 3 \times 2$-intensidade (em aumento, em diminuição e constante), tom (ascendente, descendente e constante) e ritmo (rápido e vagaroso) -. As variações destes rasgos dão como resultado 18 versões do mesmo logo sonoro. Este logo tem uma duração de 3 segundos e vai acompanhado de uma marca desconhecida e uma mensagem de voz de 9 segundos. Os resultados indicam que os logos sonoros mais vagarosos e com uma intensidade em aumento geram uma sensação mais agradável e de simplicidade que os logos mais rápidos e com intensidade em diminuição. Por sua parte, os logos sonoros com tom descendente são percebidos como mais ordinários. Igualmente, a combinação de intensidade em aumento e tom ascendente percebe-se como menos emocionante e agressiva que a combinação de intensidade em diminuição 


\section{DISERTACIONES}

ESTUDIOS

El papel del sonido en la comunicación: contribución, funciones y efectos

ISSN: $1856-9536$

Doi: http://dx.doi.org/10.12804/revistas.urosario.edu.co/disertaciones/a.6373

Volumen 12, Número 2 / Julio-diciembre 2019

Versión PDF para imprimir desde

http://revistas.urosario.edu.co/index.php/disertaciones

e tom descendente. $O$ estudo da percepção e processamento do som de marca pode contribuir a desenvolver as teorias sobre estratégias de marca, e ter importantes aplicações na produção de planos de comunicação estratégica.

Palavras-chave: branding sonoro, rasgos sonoros, personalidade de marca, emoções, escalas auto perceptivas.

The sound is a critical mechanism of human evolution and adaptation. The processing of sound facilitates the activation of the appetitive and aversive motivation systems (Lang, 2009). Thus sound plays a principal role in human communication, mass media and all types of digital platforms and communication strategies and tools. Sound evolved as an articulated phenomenon to produce voice or as a melodic, rhythmic one to create music. Today, these sound resources have a crucial communication function in interpersonal communication, radio, television, PR events or brand experiences (Fulberg, 2003).

Sonic branding is the strategic use of sound to communicate the identity and values of a brand in the different touch points with its publics (Groves, 2007; Jackson, 2004; Krishnan, Kellaris \& Aurand, 2012). This discipline puts together the advances in branding on the one hand - brand awareness, brand equity and identity, and top of mindand those on the effects of sound features - pitch, intensity, duration and timbre of the voice, music, and silence-. The current study takes an experimental approach to the musical components of the sonic logo of brands. It also defines the sonic logo as "the auditory analog of a visual logo" (Krishnan, et al., 2012, p. 276). Conventionally, the principal role attributed to the sonic logos is to associate the brand with sounds so that it can be recognized immediately (Bonde \& Hansen, 2013; Jackson, 2004). Admittedly, the traditionally most valued sonic logos were those scoring the highest in brand recognition, such as the cases of Intel, McDonalds or Coca-Cola (Rodero, Larrea, Mas, Vázquez \& Blanco, 2014). The sound is a powerful communication resource to increase attention, raise cognition and improve recall (Bolls, 2013; Bolls \& Lang, 2003; Potter \& Dillman Carpentier, 2007; Rodero, 2015).

Sound branding puts together the field of sound from a communication perspective and of branding from a marketing one, this is the merit of sound resources to convey the values of a brand, meet the listener's cognitive and emotional processing (Vorster, 2015) and transmit brand attitudes (Argo, Popa \& Smith, 2010; Bonde \& Hansen, 2013). Specifically, new approaches and more specific studies are furthering the conceptualization of brand experiences (Brakus, Schmitt \& Zarantonello, 2009). It is possible to associate the acoustic features of sound with the product's characteristics and brand values (Brodsky, 2010; North, Hargreaves \& McKendrick, 1999; Zampini \& Spence, 2004). The objective of this study is to determine how intensity, pitch and pace variations can transmit brand personality and emotions.

The existing literature in this field has focused on the foundational, exploratory or descriptive principles of branded sound with very few empirical endeavors or experimental designs (see for exceptions Krishnan, et al., 2012). Thus the effect of the different sound features in brand values transmission remains unclear. In this study, we draw on the principals of sound studies and branding to test the self-reported emotions and brand personality values elicited by the different versions of a sonic logo (level of intensity, pitch, and pace). This study is framed 


\section{DISERTACIONES}

ESTUDIOS

El papel del sonido en la comunicación: contribución, funciones y efectos

ISSN: $1856-9536$

Doi: http://dx.doi.org/10.12804/revistas.urosario.edu.co/disertaciones/a.6373

Volumen 12, Número 2 / Julio-diciembre 2019

Versión PDF para imprimir desde

http://revistas.urosario.edu.co/index.php/disertaciones

within the information transmission field in the media and communication studies, according to which the features of image and sound carry meaningful outcomes of the message, which consider the latter with regard to the brand values transmission. More specifically, firstly, this study takes Aaker's definition of brand personality (1997) to test how sound can transmit these brands' attributes. Secondly, it takes Chion and Schafer's approach (1979) to study the communicative value and function of sound, this is the significance of the acoustic traits of sound in a communication process such as sonic logo's values transmission.

\section{Brand personality}

The strategies of brand building pursue to make the brand identifiable by the organization's audiences (LaidlerKylander, Quelch \& Simonin, 2007). For so doing, some brand practices focus on how the public defines the brand in a specific culture and socioeconomic context. Within a holistic consumer-oriented paradigm (Schmitt, 2012), the study of brand personality is part of a comprehensive brand strategy which should align all communication features.

Aaker (1997) defines brand personality as the combination of emotional and physical factors that serve to distinguish the brands and make their commercial products desirable. That is to say that brand personality is "the set of human characteristics associated with a brand" (Aaker, 1997, p. 347). Brand personality fosters an intimate relationship between consumers and the brand by associating their personal traits with this brand's personality attributes. The brand is "the set of traits of human personality relevant in describing the relationship between the consumer and the brand" (Sweeney \& Brandon, 2006, p. 645). Thus the brand personality has many positive influences on the consumer's choice: it increases the levels of trust and loyalty (Fournier, 1998); generates emotions during consumption (Biel, 1993); stimulates the active processing of information (Biel, 1993); encourages self-expression and association (Belk, 1988); provides a basis for product differentiation (Aaker, 1997), and influences attitudes toward the brand (Freling \& Forbes, 2005). The field of marketing has been applying the concept of brand personality for decades. One of the most important human traits is the genre of brands - feminine or masculine - (Grohmann, 2009).

Anthropomorphism theories ground the concept of brand personality, according to which humans tend to personify objects or ideas to facilitate its processing and interaction (Boyer, 1996; Guthrie, 1997; Fournier, 1998). Mithen and Boyer (1996) note that consumers keep a relationship with brands based on these brands' symbolic or representative power; thus brand personality is a process through which brands come to life. Therefore, in contrast with previous approaches, marketing strategies consider the brand to be an active element in their relationship with consumers.

Aaker (1997) was the first to develop and validate a scale to measure brand personality (Azoulay \& Kapferer, 2003). Aaker based his model on the psychological field of the Big Five; this is the five major dimensions of human personality (McCrae \& Costa, 1989). These dimensions found in Aaker's study are: sincerity, defined as someone down to earth, honest, wholesome and cheerful; excitement, presented as someone daring, spirited, imaginative and up to date; competence, described as someone reliable, intelligent and successful; sophistication, depicted as someone upper class and charming, and ruggedness, characterized as someone outdoorsy and tough.

Aaker combined focus groups and interviews with professionals to obtain incipient personality traits framed within these psychological constructs (dimensions). Her research used a sample of 37 brands of different categories of products (products classified as symbolic, utilitarian and symbolic-utilitarian) in the United States. This 


\section{DISERTACIONES}

ESTUDIOS

El papel del sonido en la comunicación: contribución, funciones y efectos

ISSN: $1856-9536$

Doi: http://dx.doi.org/10.12804/revistas.urosario.edu.co/disertaciones/a.6373

Volumen 12, Número 2 / Julio-diciembre 2019

Versión PDF para imprimir desde

http://revistas.urosario.edu.co/index.php/disertaciones

model has been implemented in different countries -France (Koebel \& Ladwein, 1999), Venezuela (Pirela, et al., 2004), Germany (Huber, Hermann \& Braunstein, 2000), Japan and Spain (Aaker, Benet-Martínez \& Garolera, 2001), Mexico (Álvarez-Ortiz \& Harris, 2002), Russia (Supphellen \& Kjell, 2003), Korea (Sung \& Tinkham, 2005), Brazil (Muller \& Zancan, 2012), among others-.

In 2009 Geuens, Weijters and De Wulf redefined Aaker's dimensions in a study with different types of brands: functional, image, experiential, and hedonic. This model renames the dimensions though it applies some common personality traits: responsibility (down-to-earth, stable, responsible), activity (active, dynamic, innovative), aggressiveness (aggressive, bold), simplicity (ordinary, simple), and emotionality (romantic, sentimental). The resulting 12 traits are randomized in a 1 (not characteristic for the brand) to 7 (very characteristic for the brand) Likert scale:

RQ1. What are the brand personality traits associated with the sonic logo's acoustic features?

Geuens et al. (2009) conceptualize brand personality as a component of brand identity; this is, the associations attributed to the brand by the company in all the touchpoints with consumers (Kapferer, 2008). Sensory marketing has taken a holistic approach to how perception, in general, is part of the brand experience (Krishna, 2012). Accordingly, all the communication actions (be it personal, digital, broadcast; and textual, oral communication, based on sound and music, gestures, designs and colors, stunts, employees acting) contribute to the brand's personality. However, very few studies on brand personality have focused on specific sound features. This study aims to fill this gap.

\section{Sound branding}

Experimental research on sound branding is limited. Most of it has focused on the phonemic significance of brand names (Davis, Bagchi \& Block, 2016; Klink, 2000). Some studies have evidenced the capacity of music to prompt emotions and enhance memory in advertising (Alpert, Alpert \& Maltz, 2005; Dubé, Chebat \& Morin, 1995; Lantos \& Craton, 2012), although in general studies on music as a sound branding strategy have thus far taken a general descriptive approach (Ballouli \& Heere, 2015; Bollue, 2015; Gustafsson, 2015; Jackson, 2004; Spence, et al., 2010).

Researchers have defined musical fit in branding as the connection between knowledge structures raised by music and brands (North, Mackenzie \& Law, 2004) and determined it by three elements, namely voice, lyrics, and music genre (Ballouli \& Heere, 2015). Mas, Collell, and Xifra (2017) conducted a more specific study by analyzing the acoustic features of music (pitch, intensity, and pace) to hypothesize brand personality and brand associations with the music used by Republican and Democrat parties in 2016 us elections. The evidence on the well-reported mental imaginary (Bolls, 2013; Bolls \& Lang, 2003; Kosslyn, Ganis \& Thompson, 2010; Miller \& Marks, 1992; Paivio, 1986; Schwartz, 1999), formerly defined as soundscapes (Van Leeuwen, 1999) or paysage sonore (Schafer, 1979) supported this study. This study found that the candidate Trump was using music to build a strong brand personality of himself as a patriot whereas Clinton used music to associate the brand with some democrat values.

A mental image is the capacity "to see with the eye of the mind, listen with the ear of the mind" (Kosslyn, et al., 2010, p. 3). Overall, the majority of voice and sound studies distinguish between major mode or high-pitched sounds and minor mode or low-pitched ones (Collins, 2000; Rodero, Larrea \& Vázquez, 2013). Audiences perceive the former tones as more natural and exciting, which transmit happy emotions, while the latter as calm, sad, and thoughtful emotions (Machin, 2011). 


\section{DISERTACIONES}

ESTUDIOS

El papel del sonido en la comunicación: contribución, funciones y efectos

ISSN: $1856-9536$

Doi: http://dx.doi.org/10.12804/revistas.urosario.edu.co/disertaciones/a.6373

Volumen 12, Número 2 / Julio-diciembre 2019

Versión PDF para imprimir desde

http://revistas.urosario.edu.co/index.php/disertaciones

This approach argues that the combination of intensity, pitch and pace variations inform emotional and motivational systems. These features are embedded within the capacity to distinguish voices and envision faces and physical and personality traits as a result of these voices (Larrea, 2014). In general, people perceive low pitch voices as more pleasant, powerful, mature, elegant and credible, and high pitch voices as feminine and delicate, and related to slimness and clear facial features. Despite the progress made on personality traits and voices, no research has focused on the specific attributes of brand personality scales elicited by pitch or melodic patterns associated with a brand:

RQ1.1: What are the brand personality traits associated with the sonic logo's pitch variation (ascending, descending or constant)?

This study also tries to find associations between brand personality traits and intensity variations: fade up, fade down and constant intensity:

RQ1.2: What are the brand personality traits associated with the sonic logo's intensity variation (fade up, fade down and constant)?

The third acoustic feature is the pace, which is usually characterized as fast, constant or slow:

RQ1.3: What are the brand personality traits associated with the sonic logo's pace (slow or fast)?

The pace is a critical sound feature of music. Music strongly connects with emotions (Zentner, Grandjean \& Scherer, 2008). Typically, a high paced music connects with high arousal, excitement and dynamic messages, whereas slow paced music connects with calm and less active messages (Potter \& Dillman Carpentier, 2007). Thus

H1: Slow sonic logos are expected to be significantly calmer and more pleasant than fast ones, and less active and dynamic than fast ones.

To make progress on how sound features process in a branding context, this study goes beyond the tonality of sounds and tries to define more general, meaningful patterns of sound perception (Winkler, Denham \& Nelken, 2009). In other words, sound features are put together in greater units, namely the sonic logo of a brand. Broadly speaking, the rationale of Gestalt theory can explain sound perception (Van Leeuwen, 1999). This is a perceptible mechanism used to find continuities in the auditory stimuli as if the listener was continuously hypothesizing the "casual structure of the world" (Winkler, et al., 2009, p. 532). The tendency to find regularities in the sound orients response (Rodero, 2015) and influences attitudes and behavior (Winkler, et al., 2009). According to this evolutionary and cultural process, symmetry, clarity, goodness-of-form, proportion, balance, and harmony characterize western music (Winkielman, Schwarz, Fazendeiro \& Reber, 2003; Reber, Schwarz \& Winkielman, 2004). In essence, a melody (pitch variation) as the figure that takes form within a background sound context marks western music (Schafer, 1979; Van Leeuwen, 1999). Thus, finally, intensity and pitch are perceptually connected from an adaptive evolutionary perspective. Being that the case, regularity law of the Gestalt Theory would imply matching directions between intensity and pitch: fade up and the ascending and increasing pace.

RQ2: What are the brand personality traits associated with the sonic logo's pitch and intensity (fade up and ascending versus fade down and constant)?

The pattern of regularity or "goodness-of-form" also associates with constancy; this is, with lack of change. Therefore, in a world of constant change, goodness-of-form can be equated with steadiness and predictability, namely lack of danger and thus calm or low arousal; so we could hypothesize:

$\mathrm{H} 2$ : We expect audiences to perceive constant sonic logos as significantly less active and dynamic than fast ones. 


\section{DISERTACIONES}

ESTUDIOS

El papel del sonido en la comunicación: contribución, funciones y efectos

ISSN: $1856-9536$

Doi: http://dx.doi.org/10.12804/revistas.urosario.edu.co/disertaciones/a.6373

Volumen 12, Número 2 / Julio-diciembre 2019

Versión PDF para imprimir desde

http://revistas.urosario.edu.co/index.php/disertaciones

\section{Method}

This study focuses on the sound features of a non-voiced sonic logo to find associations between intensity and pitch variations and pace with brand personality traits in a laboratory setting. The researcher designed a $3 \times 3 \times 2$ within-subjects experiment: intensity (fade up, fade down or constant), pitch (ascending, descending or constant), and pace (fast or slow) of the sonic logo. The sonic logo designed was a 3-seconds one according to the western-music pattern (1 octave and $30 \mathrm{~dB}$ variations, $4 \times 4$, upper tonality $\mathrm{C}$, with low-pitched techno instrumentation) and five notes (Krishnan, et al., 2012). A music designer produced the 18 versions of the sonic logo in Austin (Texas, us).

At the beginning of a 9 seconds voice message, participants heard the 18 versions of the sonic logo. Two male presenters in the Texas Tech Radio Station spoke the message: one was voicing the brand name $(130 \mathrm{~Hz}$ average pitch) and the other the message (110 Hz average pitch). There were 18 real but unknown brands (with no sound or written meaning in English) (ABA, 2017): HRS, wAZ, Dachser, Grunenthal, Drei, Friis, Ybarra, Mahle, Sabesp, DTs, Verbund, Moma, Gefco, Dea, Norsee, Veltins, Strock, and Afoma. A familiarity test was run to guarantee lack of previous awareness. Data indicated that the 18 target brands were not identified as they scored between 1 and 1.40 in the familiarity test (from $1-$ I have never heard of the brand - to $9-$ I love this brand-), except for HRS that scored 2.65. Although this last score is considerably higher than the rest of the target brands, it is still much lower than the scores of the 32 known brands of the test: Oberstaufen, British Airways, Trivago, Electronic Arts, Sony, Canal +, NBC, RTL, Twentieth Century Fox, Lexus, Verti, Mercedes, Green Flag, ктм, Targo Bank, easyCredit, Direct Line, Chevron, Intel, Olympus, Coca-Cola, Apollinaris, Haribo, Mister Donut, Yakult, Nott, Audi, Marche, Brand24, Wurth International, Nivea, and Bauhaus, which scored between 4 and 7-8 in this test. Overall, this familiarity test guarantees that the results will not be due to the artifact of the awareness of the brand name.

So, the sound message had the 18 versions of the sonic logo embedded, which structure is the following: sonic logo, brand name, and announcement (call to action, discount, time of the offer, brand name, final claim). The template for the announcement was year (Since 1992/1994/1996), claim (Made for you/Created for you/Designed for you), call to action (Get ready/Gear up/ Listen up), time of the offer (Special offer today, this week/this month) and the percentage of discount (Get a $5 \% / 25 \% / 50 \%$ off).

The placement of the logo (visual and sonic) at the beginning of the ad is a recent practice in campaigns in all media, including Tv as shown in 2017 T-Mobile and Netflix ad in the us. Also, Facebook and other platforms are using short 5 to 7 -seconds ads. Although this is becoming a common practice in the profession, to our knowledge, no previous studies have examined the effects of these phenomena.

To prevent artifacts, the research team randomized the resulting 18 messages across three experimental conditions with the only change of the brand names, which are also randomized across the 18 messages in condition 2 and again in condition 3 . In total 54 participants were presented the 18 versions, distributed in three conditions (16 participants in condition 1, 16 in condition 2, and 17 in condition 3 ).

Participants were recruited via sona system in Texas Tech between October $14^{\text {th }}$ and October the $28^{\text {th }} 2017$, and granted with one extra credit. The participants completed the survey individually with an approximate duration of 35 minutes. The participants' age was limited to 19 to 22 -year-olds. The mean age was 19.14 years (sD $=1.976$ ), $26.2 \%$ were men. 


\section{DISERTACIONES}

ESTUDIOS

El papel del sonido en la comunicación: contribución, funciones y efectos

ISSN: 1856-9536

Doi: http://dx.doi.org/10.12804/revistas.urosario.edu.co/disertaciones/a.6373

Volumen 12, Número 2 / Julio-diciembre 2019

Versión PDF para imprimir desde

http://revistas.urosario.edu.co/index.php/disertaciones

Therefore, the independent variables are the intensity variations (fade up, fade down, constant), the pitch (ascending, descending, constant), and the pace (fast, slow). The 18 versions of the message had those three variables crossed. Finally, the participants heard them and responded to three dependent variables. Firstly, the participants received a self-reported scale on emotions, a 1-9 semantic differential on calm/excited; secondly, two 1-9 Likert scales (not at all, extremely) on the variable pleasantness and unpleasantness. Lastly, they received a brand personality scale (1-7 Likert scale, 12 randomized items) (Geuens, Weijters \& De Wulf, 2009). One-way Anova and $t$ tests were applied to show significant differences between versions of sonic logos with acoustic variances.

\section{Results}

This research focuses on the self-reported emotion (calm/excited) and the level of pleasantness and unpleasantness raised by each type of sonic logo, as well as whether or not the 12 personality traits characterize the sound brand. These measures are applied to slow or fast sonic logos; ascending, descending or constant (pitch) sonic logos; fade up, fade down or constant (intensity) sonic logos; and arousing (fade up plus ascending) or non-arousing (fade down plus descending and constant) sonic logos.

Firstly, the researcher applied a one-way Anova statistic to the ascending, descending and constant sonic logos. The degree of emotion is significantly different between sonic logos $-F(2,879)=3.810, p<.05-$, being the constant more exciting ( $M=3.49)$ than the ascending $(M=3.03)$ and the descending sonic logo $(M=3.18)$. The post-hoc test of Tukey HSD showed significant differences $(p<.05)$ between constant and ascending logos. Regarding personality traits, the descending logo is considered more down-to-earth $(M=3.52)$ and simpler $(M=4.83)$ than the ascending $(\mathrm{M}=3.40$ and $\mathrm{M}=4.32$ respectively) or the constant sonic $\log (\mathrm{M}=3.11$ and $\mathrm{M}=4.42$ respectively $)-F(2,879)=3.362$ and 3.330 respectively, $p<.05-$ (see table 1 ). The post-hoc test of Tukey HSD showed significant differences $(p<.05)$ between descending and constant sonic logos with regard to these two brand personality traits.

Table 1. Self-reported emotion and main traits associated pitch

\begin{tabular}{|c|c|c|c|}
\hline & Exciting/calm* & Down-to-earth* & Simplicity $^{\star}$ \\
\hline Ascending & 3.03 & 3.40 & 4.32 \\
\hline Descending & 3.18 & 3.52 & 4.83 \\
\hline Constant & 3.49 & 3.11 & 4.42 \\
\hline
\end{tabular}

* $p<.05$

So, in general, in response to RQ1.1, constant pitch sonic logos were perceived as more exciting than ascending sonic logos. Although there was no hypothesis was on the degree of emotion of sonic logos' melodic pattern, emotional arousal tends to connect with ascending pitch; thus this piece of results seems counterintuitive and non-conclusive. As the other two scales of emotions showed no significant differences, these data may be the result of artifacts and more research is needed on this issue. What seems more logical is the descending sonic logos to be perceived as significantly more down-to-earth and simple than ascending or constant sonic logos. 


\section{DISERTACIONES}

\section{ESTUDIOS}

Secondly, a one-way Anova statistic was applied to the fade up, fade down and constant sonic logos. The degree of pleasantness was significantly different between sonic logos $-F(2,879)=3.075, p<.05-$. In response to RQ1.2, fade up sonic logos are more pleasant $(M=5.34)$ than the fade down $(M=4.93)$ and the constant intensity in the sonic logo $(M=5.17)$. The post-hoc test of Tukey HSD showed significant differences $(p<.05)$ between fade up and fade down (see table 2). This is in line with the gestalt laws of good form and regularity, as well as the semantic connection between increasing intensity and being well -happy, excited, pleased-. There were no significant differences in the one-way Anova or the Poshoc T3 of Dunnet between the three sound features regarding the brand personality traits.

Table 2. Self-reported emotion raise by intensity

\begin{tabular}{|l|c|c|c|}
\hline & Exciting/calm & Pleasantness* $^{*}$ & Unpleasantness \\
\hline Fade up & 3.07 & 5.34 & 3.85 \\
\hline Fade down & 3.35 & 4.93 & 3.74 \\
\hline Constant & 3.32 & 3.18 & 3.62 \\
\hline
\end{tabular}

${ }^{*} p<.05$

Thirdly, researchers applied the $t$ of Student to the binomial slow versus fast sonic logos. In this regard, three items show significant differences: slow sonic logos are slightly more pleasant $(M=5.17, F=5.434, p<.05)$ and perceived as simpler $(M=4.65, F=4.248, p<.05)$ than fast sonic $\operatorname{logos}(M=5.14$ and $M=4.65)$; and fast sonic logos are perceived as more ordinary than slow ones $(M=4.39$ versus $M=4.32)$ (see table 3 ).

Table 3. Self-reported emotion and main traits associated pace

\begin{tabular}{|c|c|c|c|}
\hline & Pleasantness* & Simplicity* & Ordinary* $^{*}$ \\
\hline Slow & 5.17 & 4.65 & 4.32 \\
\hline Fast & 5.14 & 4.65 & 4.39 \\
\hline
\end{tabular}

* $p<.05$

In response to RQ1.3, slow sonic logos are more pleasant and felt as simpler than fast sonic logos. $\mathrm{H} 1$ partially predicted this result: slow sonic logos were expected to be calmer and more pleasant than fast ones. $\mathrm{H} 1$ also predicted slow sonic logos to be less active and dynamic than fast ones, but differences on these two personality traits were not significant.

Fourth, the team also applied the $t$ of Student to arousing or non-arousing sonic logos. The Levene's test showed significant differences between these two regarding the degree of emotion $(F=6.766, p<.05)$ and the traits down-to-earth $(F=4.808, p<.05)$ and aggressive $(F=6.042, p<.05)$, the arousing sonic logos being less exciting ( $M$ $=2.88)$ than the non-arousing $(M=3.43)$, more down-to-earth $(M=3.81$ and $M=3.18)$ and less aggressive $(M=2.26$ and $M=2.77$ ) (see table 4). 


\section{DISERTACIONES}

El papel del sonido en la comunicación: contribución, funciones y efectos

ISSN: 1856-9536

Doi: http://dx.doi.org/10.12804/revistas.urosario.edu.co/disertaciones/a.6373

Volumen 12, Número 2/ Julio-diciembre 2019

Versión PDF para imprimir desde

http://revistas.urosario.edu.co/index.php/disertaciones

Table 4. Self-reported emotion and main traits associated level of arousing

\begin{tabular}{|l|c|c|c|}
\hline & Exciting/calm & Down-to-earth $^{*}$ & Aggressiveness $^{*}$ \\
\hline Arousing & 2.88 & 3.81 & 2.26 \\
\hline Non-arousing & 3.43 & 3.18 & 2.77 \\
\hline
\end{tabular}

${ }^{*} p<.05$

In response to RQ2, participants felt the arousing sonic logos (ascending pitch and fade up) as less exciting, more down-to-earth and less aggressive than the non-arousing. Finally, hypothesis $2(\mathrm{H} 2)$ expected participants to sense constant sonic logos as significantly less active and dynamic than fast sonic logos; however, Levene's test did not confirm this because it showed no significant differences between the two types of sonic logos.

In general, findings show that participants consider slow and fade up sonic logos as more pleasant while slow and descending, as simpler. Ordinary trait is associated with fast sonic logos and down-to-earth with descending and arousing (see table 5). In other words, slowness in sonic logos is associated with simplicity and pleasantness, descending with simplicity and down-to-earth, and arousing is less-aggressive and down-to-earth.

Table 5. General traits of the sonic logos

\begin{tabular}{|c|c|}
\hline Traits & Acoustic variables \\
\hline \multirow{2}{*}{ More pleasant } & Slow \\
\cline { 2 - 2 } Simple & Fade up \\
\hline Ordinary & Slow \\
\cline { 2 - 2 } & Descending \\
\hline Exciting & Fast \\
\hline & Constant \\
\hline Down-to-earth & Non arousing \\
\hline & Descending \\
\hline Less aggressive & Arousing \\
\hline
\end{tabular}

\section{Conclusions}

This study is the first, to our knowledge, to try finding associations between brand personality traits of brands from a great range of product industries and the basic sound features from the sound branding arena. Obviously, the results reported are far from being conclusive, and further research is required. However, this study does provide with some insights and does point to future directions of research on this topic. 


\section{DISERTACIONES}

ESTUDIOS

El papel del sonido en la comunicación: contribución, funciones y efectos

ISSN: $1856-9536$

Doi: http://dx.doi.org/10.12804/revistas.urosario.edu.co/disertaciones/a.6373

Volumen 12, Número 2 / Julio-diciembre 2019

Versión PDF para imprimir desde

http://revistas.urosario.edu.co/index.php/disertaciones

The brand personality traits down-to-earth and simplicity are the most used to describe sonic logos, which reinforces their main function: to be recognized easily. Any sound design for brand purposes should be thought in these terms: simplicity and recognizable. In this sense, listeners feel a descending or constant pitch as the most suitable to be down-to-earth and simple, while intensity variations do not seem to play a major role. This is coincident with most sound studies, which tend to discard intensity as an important communication resource.

Regarding the emotions raised by the sound features of the sonic logo, the study did not find significant differences between the versions. As expected, participants perceived slow sonic logos as calmer and more pleasant, but fast or arousing sonic logos were not considered more active or dynamic. Also, unexpectedly, constant pitch logos were perceived as more exciting. Clearly, the fact that only one scale of emotions showed significant differences between the three-pitched levels casts doubt on the validity of this finding. Also, no theoretical grounds would support this, but the opposite (Rodero, 2015). Admittedly, self-reported scales on emotions need to be complemented by pshycophysiological measures (Potter \& Bolls, 2012). This research shows the need to collect data on how listeners psychophysiologically process arousing sounds (ascending pitch, mainly) in a sound branding context. To our knowledge, no prior studies on sound branding have taken this approach.

Overall, this study makes a specific contribution to sound branding studies: it shows the specific brand personality traits used by audiences to define and identify sonic logos and how they associate them with slow versus fast sonic logos on the one hand, and ascending versus descending or constant ones on the other. Researchers could not interpret the results any further. However, being the first of its kind, this study should be taken as an insightful attempt to link sound and Geuens et al.'s (2009) brand personality scale. Needless to say, research on sound branding should make progress on all fronts, in particular, the contribution of music to brand experiences in stores and PR events.

The advent of the portable or wearable ICTS and the new models of marketing, PR and branding, have established a new paradigm in which researchers and practitioners should collaborate to make the most of sound's capacity to create atmospheres in each cultural, social and commercial setting (Rodero, et al., 2014) and transmit emotional brand values (Jackson \& Jankovich, 2013; Spence, 2008, 2012; Spence, et al., 2010). Society lives today in a media ecosystem determined by embodied all-embracing communication devices and expanding universal social networks. The capacity of sound to be processed in a paralleled fashion to daily tasks gives great opportunities for strategic communication. Most of the brand-related information occurs subconsciously; thus the interest in neuromarketing and multisensory marketing is growing (Krishna, 2012). In this vein, the musicality of brands can elicit sensory experiences such as smell, touch, or visual images.

\section{Discussion}

Research on information transmission in communication processes started many decades ago. Since the establishment of the Media Psychology field of study, the methods applied to the study of the effects of image and sound features have become solid and rigorous. Despite the reduced amount of scholar dedicated to the study of sound features, the specificity of this line of research has led to significant progress. There are few studies on how sound elements (voices, effects) can elicit orienting response, or how the pace and the duration of sound features can communicate rhythm. Only recently are some scholars focusing on the melodic patterns of voice as a way of 


\section{DISERTACIONES}

ESTUDIOS

El papel del sonido en la comunicación: contribución, funciones y efectos

ISSN: $1856-9536$

Doi: http://dx.doi.org/10.12804/revistas.urosario.edu.co/disertaciones/a.6373

Volumen 12, Número 2 / Julio-diciembre 2019

Versión PDF para imprimir desde

http://revistas.urosario.edu.co/index.php/disertaciones

transmitting information and raising emotions. In general, more work is required on how the main four acoustic features (pitch, duration, intensity and timbre) can be used as a code to communicate through music, voice and effects.

The study presented was framed within the information transmission field of research in communication. However, scholars have been brought to use sound study's tradition as a guiding source of knowledge due to the lack of solid theoretical foundation on sound informative features. This study reviewed the most important foundations of how communication uses sound. In essence we took an evolutionary approach according to which acoustic features are melodic elements associated with emotions, namely the approach effect of fade up, the increase in excitement of ascending pitch and fast pace, among others. On the basis of these propositions, this study focuses on how acoustic features may be associated with brand values.

Branding is a rather new discipline. The application of sound studies to branding runs parallel to the conceptualization of branding strategies. This can be very informative to this field, especially bearing in mind that branding is focusing on the conceptualization of brand experiences (Brakus, Schmitt \& Zarantonello, 2009) as a connection between sensory fluxes of communication (be it a smell, light or music) and the publics' emotional responses (De Chernatony, 2001). Findings of this study should be interpreted within this framework.

In this regard, this study found out that simplicity and pleasantness correlate with slow and fade up sonic logos and personality traits down-to-earth and ordinary with descending sonic logos. These results are far from conclusive but are insightful on the importance of these specific personality traits in branding -simplicity, downto-earth and, ordinary - and the need of testing acoustic patterns associated to brands with psychophysiological measures. In such a new field of research, we can say that many personal and social factors influence self-reported measures; thus the use of dynamic physiological ones is a requirement. This is the major limitation of this study, and the reason to discard some counterintuitive and counter-theoretical results as those on pitch variations. The cognitive nature of effects may influence the diverted perception of pitch. In other words, participants cannot be aware of the emotions raised by the melodic patterns of sonic logos; hence the application of psychophysiology is mandatory.

The majority of results reported are insightful of the emotional effects of sonic logos on the basis of sound perception foundations. This is sonic logos can transmit values such as simplicity, ordinariness and down-to-earth, which associate with the perceptive patterns of sound: fast or slow pace, fading and ascending or descending pitch form. In sum, these results are only an exploratory endeavor on how brand personality traits experimentally associate with branded sound. Although the research did not allow to extract conclusive results, this is a starting point to fine tune this type of designs.

Finally, this study can have important implications in branding. Brands should strategically design their sonic logos according to the acoustic patterns of sound. The use of simple, ordinary and down-to-earth patters can elicit recognition of the sonic logo. Future endeavors should give more insight on how to transmit specific brand merits. We strongly encourage the correlation of psychophysiological measures with brand personality scales. Also, qualitative work on the meaning and values of well-known brands and industry categories could correlate with the significance and virtues of sound. 


\section{DISERTACIONES}

ESTUDIOS

El papel del sonido en la comunicación: contribución, funciones y efectos

ISSN: $1856-9536$

Doi: http://dx.doi.org/10.12804/revistas.urosario.edu.co/disertaciones/a.6373

Volumen 12, Número 2 / Julio-diciembre 2019

Versión PDF para imprimir desde

http://revistas.urosario.edu.co/index.php/disertaciones

\section{References}

1. Aaker, J. (1997). Dimensions of brand personality. Journal of Marketing Research, 34(3), 347-356. Doi: http://dx.doi.org/10.2307/3151897

2. Aaker, J., Benet-Martínez, V., \& Garolera, J. (2001). Consumption symbols as carries of culture: A study of Japanese and Spanish brand personality constructs. Journal of Personality \& Social Psychology, 81(3), 492508. Doi: http://dx.doi.org/10.1037/0022-3514.81.3.492

3. ABA, Audio Branding Academy. (2017). Retrieved from http://audio-branding-academy.org/

4. Alpert, M. I., Alpert, J. I., \& Maltz, L. N. (2005). Purchase occasion influence on the role of music in advertising. Journal of Business Research, 58, 369-376. Doi: https://doi.org/10.1016/S0148-2963(03)00101-2

5. Álvarez-Ortiz, C., \& Harris, J. (2002). Assessing the structure of Brand personality among global and local Mexican brands. In AmmA Summer Educators Conference, San Diego, CA, USA.

6. Argo, J., Popa, M., \& Smith, M. (2010). The sound of brands. Journal of Marketing, 97-109. Doi: https://doi. org/10.1509/jmkg.74.4.97

7. Azoulay, A., \& Kapferer, J. (2003). Do brand personality scales really measure brand personality? Journal of Brand Management, 11(2), 144. Doi: http://dx.doi.org/10.1057/palgrave.bm.2540162

8. Ballouli, K., \& Heere, B. (2015). Sonic branding in sport: a model for communicating brand identity through musical fit. Sport Management Review, 18(3), 321-330. Doi: https://doi.org/10.1016/j.smr.2014.03.001

9. Belk, R. W. (1988). Possessions and the extended self. Journal of Consumer Research, 15(2), 139-168. Doi: http://dx.doi.org/10.1086/209154

10. Biel, A. (1993). Converting image into equity. In D. Aaker \& A. Biel (Eds.), Brand equity and advertising (pp. 67-82). New Jersey, Estados Unidos: Hillsdale, Lawrence Erlbaum.

11. Bolls, P. (2013). I can hear you, but can i see you? The use of visual cognition during exposure to high-imagery advertisements. Communication Research, 29, 537. Doi: 10.1177/009365002236194

12. Bolls, P., \& Lang, A. (2003). I saw it on the radio: the allocation of attention to high-imagery radio advertisements. Media Psychology, 5, 33-55. Doi: http://dx.doi.org/10.1207/S1532785XMEP0501_2

13. Bollue, S. (2015). Sonic branding: a framework for understanding sound branding and an overview of its most notable practices across industries (Bachelor Thesis, University of Applied Sciences, Finland). Retrieved from http://www.theseus.fi/handle/10024/97285

14. Bonde, A., \& Hansen, G. A. (2013). Audio logo recognition, reduced articulation and coding orientation: rudiments of quantitative research integrating branding theory, social semiotics and music psychology. SoundEffects, 3, 1-2.

15. Boyer, P. (1996). What makes anthropomorphism natural: intuitive ontology and cultural representations. Journal of the Royal Anthropological Institute, 2(1), 83-97. Doi: http://dx.doi.org/10.2307/3034634

16. Brakus, J., Schmitt, B., \& Zarantonello, L. (2009). Brand experience: what is it? How is it measured? Does it affect loyalty? Journal of Marketing, 73(3), 52-68. Doi: http://dx.doi.org/10.1509/jmkg.73.3.52

17. Brodsky, W. (2010). Developing a functional method to apply music in branding: design language-generated music. Psychology of Music, 39(2), 261-283. Doi: https://doi.org/10.1177/0305735610387778 


\section{DISERTACIONES}

ESTUDIOS

El papel del sonido en la comunicación: contribución, funciones y efectos

ISSN: $1856-9536$

Doi: http://dx.doi.org/10.12804/revistas.urosario.edu.co/disertaciones/a.6373

Volumen 12, Número 2 / Julio-diciembre 2019

Versión PDF para imprimir desde

http://revistas.urosario.edu.co/index.php/disertaciones

18. Collins, S. A. (2000). Men's voices and women's choices. Animal Behaviour, 60, 773-780. Doi: https://doi. org/10.1006/anbe.2000.1523

19. Davis, D. F., Bagchi, R., \& Block, L. G. (2016). Alliteration alters: phonetic overlap in promotional messages influences evaluations and choice. Journal of Retailing, 92(1), 1-12. Doi: https://doi.org/10.1016/j. jretai.2015.06.002

20. De Chernatony, L. (2001). A model for strategically building brands. The Journal of Brand Management, 9(1), 32-44. Doi: http://dx.doi.org/10.1057/palgrave.bm.2540050

21. Dubé, L., Chebat, J. C., \& Morin, S. (1995). The effects of background music on consumers' desire to affiliate on buyer-seller interactions. Psychology \& Marketing, 12(4), 305-319. Doi: 10.1002/mar. 4220120407

22. Fournier, S. (1998). Consumers and their brands: developing relationship theory in consumer research. Journal of Consumer Research, 24(4), 343-353. Doi: http://dx.doi.org/10.1086/209515

23. Freling, T., \& Forbes, L. (2005). An examination of brand personality through methodological triangulation. Journal of Brand Management, 13(2), 148-162. Doi: http://dx.doi.org/10.1057/palgrave.bm.2540254

24. Fulberg, P. (2003). Using sonic branding in the retail environment -an easy and effective way to create consumer brand loyalty while enhancing the in-store experience-. Journal of Consumer Behaviour, 3(2), 193-198. Doi: 10.1002/cb.132

25. Geuens, M., Weijters, B., \& De Wulf, K. (2009). A new measure of brand personality. International Journal of Research in Marketing, 26, 97-107. Doi: https://doi.org/10.1016/j.ijresmar.2008.12.002

26. Grohmann, B. (2009). Gender dimensions of brand personality. Journal of Marketing Research, 46(1), 105119. Doi: http://dx.doi.org/10.1509/jmkr.46.1.105

27. Groves, J. (2007). A short history of sound branding. In K. Bronner \& R. Hirt (Eds.), Audio branding: Entwicklung, Anwendung, Wirkung akustischer Identitäten in Werbung, Medien und Gesellschaft (pp. 40-51). Munich, Germany: Reinhard Fischer.

28. Gustafsson, C. (2015). Sonic branding: a consumer-oriented literature review. Journal of Brand Management, 22(1), 20-37. Doi: https://doi.org/10.1057/bm.2015.5

29. Guthrie, S. (1997). Anthropomorphism: a definition and a theory. In R. W. Mitchell, N. S. Thompson \& H. L. Miles (Eds.), Anthropomorphism, anecdotes and animals (pp. 50-58). Albany: State University of New York Press.

30. Huber, F., Hermann, A., \& Braunstein, C. (2000). The brand personality as a determinant of brand loyalty, findings of an empirical study in the automobile sector. Developments in Marketing Science, 23, 340-346. Doi: http://dx.doi.org/10.1007/978-3-319-11885-7_81

31. Jackson, D. (2004). Sonic branding. New York: Palgrave McMillan.

32. Jackson, D. M., \& Jankovich, R. (2013). Hit brands: how music builds value for the world's smartest brands. Hampshire: Palgrave Macmillan.

33. Kapferer, J. N. (2008). The new strategic brand management. Creating and sustaining brand equity long term. Kokan Page: London \& Philadelphia.

34. Klink, R. R. (2000). Creating brand names with meaning: the use of sound symbolism. Marketing Letters, 11(1), 5-20. Doi: https://doi.org/10.1023/A:1008184423824

35. Koebel, M., \& Ladwein, R. (1999). L'échelle de personnalité de la marque de Jennifer Aaker: adaptation au contexte français. Decisions Marketing, 18, 81-88. Doi: http://www.jstor.org/stable/40592670 


\section{DISERTACIONES}

ESTUDIOS

El papel del sonido en la comunicación: contribución, funciones y efectos

ISSN: $1856-9536$

Doi: http://dx.doi.org/10.12804/revistas.urosario.edu.co/disertaciones/a.6373

Volumen 12, Número 2 / Julio-diciembre 2019

Versión PDF para imprimir desde

http://revistas.urosario.edu.co/index.php/disertaciones

36. Kosslyn, S., Ganis, G., \& Thompson, W. (2010). Multimodal images in the brain. In A. Guillot \& C. Collet (Eds.), The neurophysiological foundations of mental and motor imagery (pp. 3-16). Oxford Scholarship. Doi: 10.1093/acprof:oso/9780199546251.003.0001

37. Krishna, A. (2012). An integrative review of sensory marketing: engaging the senses to affect perception, judgment and behavior. Journal of Consumer Psychology, 22(3), 332-351. Doi: https://doi.org/10.1016/j. jcps.2011.08.003

38. Krishnan, V., Kellaris, J. J., \& Aurand, T. W. (2012). Sonic logos: can sound influence willingness to pay? Journal of Product \& Brand Management, 21(4), 275-284. Doi: 10.1108/10610421211246685

39. Laidler-Kylander, N., Quelch, J., \& Simonin, B. (2007). Building and valuing global brands in the nonprofit sector. Nonprofit Management and Leadership, 17(3). Doi: 10.1002/nml.149

40. Lang, A. (2009). The limited capacity model of motivated media message processing. In R. L. Nabi \& M. B. Oliver (Eds.), The SAGE handbook of media processes and effects (pp. 193-204). Thousand Oaks, CA: SAGE Publications.

41. Lantos, G. P., \& Craton, L. G. (2012). Model of consumer response to advertising music. Journal of Consumer Marketing, 29(1), 22-42. Doi: 10.1108/07363761211193028

42. Larrea, O. (2014). Estudio sobre la escucha de la voz del locutor con y sin su imagen: análisis del proceso perceptivo y cognitivo del oyente (PhD Thesis, Pompeu Fabra University). Retrieved from https://repositori.upf.edu/handle/10230/23624

43. Machin, D. (2011). Towards a social semiotic approach of the analysis of emotion in sound and music. The Public Journal of Semiotics, III(2), 152-174. Retrieved from http://pjos.org/index.php/pjos/article/ view/8835

44. Mas, L., Collell, J., \& Xifra, J. (2017). The sound of music or the history of trump and clinton family singers: music branding as communication strategy in 2016 presidential campaign. American Behavioral Scientist, 61(6), 584-599. Doi: https://doi.org/10.1177/0002764217701214

45. McCrae, R., \& Costa, P. (1989). The structure of interpersonal traits: Wiggins's circumplex and the five-factor model. Journal of Personality and Social Psychology, 56(4), 586-595. Doi: http://dx.doi. org/10.1037//0022-3514.56.4.586

46. Miller, D. W., \& Marks, L. J. (1992). Mental imagery and sound effects in radio commercials. Journal of Advertising, 21(4), 83-93. Doi: http://dx.doi.org/10.1080/00913367.1992.10673388

47. Mithen, S., \& Boyer, P. (1996). Anthropomorphism and the evolution of cognition man. Journal of the Royal Anthropological Institute, 2(4), 717-721. Doi: 10.1016/anbe.2002.2001

48. Muller, K., \& Zancan, R. (2012). Brand personality dimensions in the Brazilian context. Brazilian Administration Review, 9(2), 168-188. Doi: http://dx.doi.org/10.1590/s1807-76922012000200004

49. North, A. C., Hargreaves, D. J., \& McKendrick, J. (1999). The influence of in-store music on wine selection. Journal of Applied Psychology, 84(2), 271-276. Doi: http://dx.doi.org/10.1037/0021-9010.84.2.271

50. North, A. C., MacKenzie, L. C., \& Law, R. M. (2004). The effects of musical and voice "fit" on responses to advertisements. Journal of Applied Social Psychology, 34(8), 1675-1708. Doi: 10.1111/j.1559-1816.2004. tb02793.x

51. Paivio, A. (1986). Mental representations: a dual coding approach. New York: Oxford University Press. 


\section{DISERTACIONES}

ESTUDIOS

El papel del sonido en la comunicación: contribución, funciones y efectos

ISSN: $1856-9536$

Doi: http://dx.doi.org/10.12804/revistas.urosario.edu.co/disertaciones/a.6373

Volumen 12, Número 2 / Julio-diciembre 2019

Versión PDF para imprimir desde

http://revistas.urosario.edu.co/index.php/disertaciones

52. Pirela, J., Villavicencio, H., \& Saavedra, J. (2004). Dimensiones de personalidad de marca. Estudio exploratorio en Venezuela. Revista de Ciencias Sociales, 10(3), 430-440.

53. Potter, R. F., \& Bolls, P. (2012). Psychophysiological measurement and meaning: cognitive and emotional processing of media. New York: Routledge.

54. Potter, R. F., \& Dillman Carpentier, F. R. (2007). Effects of music on physiological arousal: explorations into tempo and genre. Media Psychology, 10(3), 339-363. Doi: http://dx.doi.org/10.1080/15213260701533045

55. Reber, R., Schwarz, N., \& Winkielman P. (2004). Processing fluency and aesthetic pleasure: is beauty in the perceiver's processing experience? Personality and Social Psychology Review, 8(4), 364-382. Doi: 10.1207/ s15327957pspr0804_3

56. Rodero, E. (2015). The spark orientation effect for improving attention and recall. Communication Research, on line before print. Doi: https://doi.org/10.1177/0093650215609085

57. Rodero, E., Larrea, O., \& Vázquez, M. (2013). Male and female voices in commercials. Analysis of effectiveness, adequacy for product, attention and recall. Sex Roles, 68(5), 349-362. Doi: https://doi.org/10.1007/ s11199-012-0247-y

58. Rodero, E., Larrea, O., Mas, L., Vázquez, M., \& Blanco, M. (2014). When the internet seems to be deaf. Sound resources to enrich online radio advertising. In M. Oliveira \& F. Ribeiro (Eds.), Radio, sound and internet (pp. 362-372). Braga: Proceedings of Net Station International Conference-cEcs.

59. Schafer, M. (1979). Le paysage sonore. Paris: Jean-Calude Lattés.

60. Schmitt, B. (2012). The consumer psychology of brands. Journal of Consumer Psychology, 22, 7-17. Doi: https://doi.org/10.1016/j.jcps.2011.09.005

61. Schwartz, D. L. (1999). Physical imagery: kinematic versus dynamic models. Cognitive Psychology, 38(3), 433-64. Doi: 10.1006/cogp.1998.0702

62. Spence, C. (2008). Auditory product design: new methods for evaluating the influence of changes in product sound on product evaluation. Proceedings of the Institute of Acoustics, 30(4), 31-38. Retrieved from https:// ora.ox.ac.uk/objects/unid:52bae456-44fb-47a3-a3a3-171e2ae88ca9

63. Spence, C. (2012). Managing sensory expectations concerning products and brands: capitalizing on the potential of sound and shape symbolism. Journal of Consumer Psychology, 22(1), 37-54. Doi: https://doi. org/10.1016/j.jcps.2011.09.004

64. Spence, C., Shankar, M. U., \& Blumenthal, H. (2010). Sound bites: auditory contributions to the perception and consumption of food and drink. In F. Bacci \& D. Melcher (Eds.), Art and the senses (pp. 207-238). Oxford: Oxford University Press.

65. Sung, Y., \& Tinkham, S. (2005). Brand personality in the United States and Korea: common and culture-specific factors. Journal of Consumer Psychology, 15(4), 334-350. Doi: http://dx.doi.org/10.1207/ s15327663jcp1504_8

66. Supphellen, M., \& Kjell, G. (2003). Building foreign brand personalities in Russia: the moderating effect of consumer ethnocentrism. International Journal of Advertising, 22(2), 203-226.

67. Sweeney, J., \& Brandon, C. (2006). Brand personality: exploring the potential to move from factor analytical to circumplex models. Psychology and Marketing, 23(8), 639-663. Doi: http://dx.doi.org/10.1002/mar.20122

68. Van Leeuwen, T. (1999). Speech, music and sound. London, Great Britain: MacMillan Press. 


\section{DISERTACIONES}

69. Vorster, I. A. (2015). The influence of sonic logos in television advertisements: a neuromarketing perspective (PhD Thesis, Faculty of Business Management, Stellenbosch University). Retrieved from http://scholar. sun.ac.za/handle/10019.1/97892

70. Winkielman, P., Schwarz, N., Fazendeiro, T. A., \& Reber, R. (2003). The hedonic marking of processing fluency: implications for evaluative judgment. In J. Musch \& K. C. Klauer (Eds.), The Psychology of evaluation: affective processes in cognition and emotion (pp. 189-217). Mahwah, NJ: Lawrence Erlbaum.

71. Winkler, I., Denham, S. L., \& Nelken, I. (2009). Modeling the auditory scene: predictive regularity representations and perceptual objects. Cell Press. Doi: 10.1016/j.tics.2009.09.003

72. Zampini, M., \& Spence, C. (2004). The role of auditory cues in modulating the perceived crispness and staleness of potato chips. Journal of Sensory Science, 19, 347-363. Doi: 10.1111/j.1745-459x.2004.080403.x

73. Zentner, M., Grandjean, D., \& Scherer, K. R. (2008). Emotions evoked by the sound of music: characterization, classification, and measurement. Emotion, 8(4), 494-521. 